r ScIDioc

\section{Factors Associated with Umbilical Cord Blood Derived Mononuclear Cells Banking in Morocco: A Preliminary Study}

\section{International Journal of Stem Cell Research and Transplantation (IJST)} ISSN: 2328-3548

\author{
Mazini L*, Ouafa O, Charoute H, Elmdaghri N
}

Laboratoire Cellules Souches et Thérapie Cellulaire, Institut Pasteur Maroc, Casablanca, Place Pasteur, Casablanca, Morocco.

\title{
Abstract
}

Umbilical cord blood (UCB) is commonly used as the main heamatopoietic stem cell (HSC) source for allogeneic transplantation. Immediately available when compared to bone marrow (BM), UCB is now widely processed and stored as rigorously qualified units. These units were firstly estimated before processing using specific criteria for the donor's choice, and by parameters such as Total Nucleated Cells (TNC), Mononuclear Cells (MNC), CD34+ cells and Colony Forming Units (CFU) for final processing. Appropriate assessment of factors related to maternal, obstetrical and neonatal variables showed these variables as the mainly contributors to a better UCB quality management. This preliminary study aimed to identify the effects of parameters such as maternal age, weight, gravid status, delivery mode, neonatal weight and gender on the MNC count in more 18 years old aged consent, and 33 full-term gravid donors. MNC count did not depend on gravid status and maternal age and weight as well as delivery mode and gender. However, neonatal weight and MNC counts appeared slightly associated independently to maternal age. This work might be helpful in developing and controlling procedures prior to UCB manipulation and would be improved for more UCB eligibility after bank creation.

Keywords: Umbilical Cord Blood Banking; Maternal and Neonatal Factors; MNC, Morocco.

Abbreviations: BM: Bone Marrow; CFU: Colony Forming Unit; HLA: Human Leukocyte Antigen; HSC: Heamatopoietic Stem Cells; MNC: Mononuclear Cells; UCB: Umbilical Cord Blood; TNC: Total Nucleated Cells.

\section{Introduction}

Umbilical Cord Blood (UCB) is increasingly used as an alternative source of stem cells since the first successful transplantation into a patient with a Fanconi's Anemia [1]. These cells are able to reconstitute stem cell disorders in vivo, and are the firstly considered for allogeneic transplantation and banking [2]. Several thousand of clinical applications using UCB have been conducted despite of the low blood volume collected and the non eligibility of collected units. Indeed, developing practical and efficient methods have showed that only $29 \%$ of collected UCB units remained suitable for banking [3]. To ensure their quality, different variables such as donor choice, collection process, collected volume, Total Nucleated Cells (TNC), Mononuclear Cells (MNC), total CD34+ cell counts were assessed [2]. However, there is still controversy regarding evaluation of UCB unit's safety and potency. Using standardized protocols and conditioning regimens, outcome and engraftment in UCB transplantation were primarily dependent on HLA disparity [4]. But, infused TNC or MNC dose have been repeatedly associated with engraftment success $[5,6]$. At this fact, collected volume is strongly considered as the first indicators for stem cell abundance $[4,6,7]$, allowing thus decision to proceed and bank. Interestingly, other variables such as maternal age, weight, parity, type of delivery, gestational age, newborn weight, height, sex [5, 8-10] and also pre-birth characteristics [11] might influence differently CD34+ and TNC or MNC counts. These aspects were analysed in many UCB banks to develop standard common procedures and quality control tools for banking.

In Morocco, published data on UCB banking are still missing. Some population characteristics are widely shared in North Africa such as fertility, caesareans deliveries [12] and obesity [13] and

*Corresponding Author

Mazini Loubna,

Laboratoire Cellules Souches et Thérapie Cellulaire, Institut Pasteur Maroc, Casablanca, 1 Place Pasteur, 20360 Casablanca, Morocco.

Email: loubna.mazini@pasteur.ma

Received: November 28, 2016

Accepted: December 09, 2016

Published: December 12, 2016

Citation: Mazini L*, Ouafa O, Charoute H, Elmdaghri N (2016) Factors Associated with Umbilical Cord Blood Derived Mononuclear Cells Banking in Morocco: A Preliminary Study. Int J Stem Cell Res Transplant. 4(10), 260-264. doi: http://dx.doi.org/10.19070/2328-3548-1600040

Copyright: Mazini $L^{\circ}$ 2016. This is an open-access article distributed under the terms of the Creative Commons Attribution License, which permits unrestricted use, distribution and reproduction in any medium, provided the original author and source are credited. 
might be used as UCB banking indicators having to be assessed. This preliminary study aims to evaluate the donors profile as the mainly selection parameter for the UCB quality assessment. A specific questionnaire about the mostly associated maternal and neonatal characteristics with birth was developped.

\section{Materials And Methods}

\section{Criteria Collection of Donors}

Data regarding Moroccan family and medical history were reported in a questionnaire for each donor. Exclusion criteria consisted of smoking, positive infections with HIV, Hepatitis B and C viruses, Cytomegalovirus, blood and organ transplantation history, inherited diseases, and pathological pregnancies. Inclusion criteria were Moroccan nationality, age higher than eighteen $(\geq 18)$ years old, and a gestational age of at least 33 weeks $(\geq 33)$.

\section{Collection of UCB Units}

The institutional requirements of the Institut Pasteur Ethical Committee have been respected and its authorization granted and signed consent forms from informed pregnant women are received. Samples were then collected either after normal vaginal or caesarean deliveries from the candidate for donation. Units were collected in a conservation medium composed with RPMI (Gibco, Invitrogen) at 10\% EDTA (Gibco, Life Technologies), 5\% Bovine Foetal Sera (BFS, Gibco Invitrogen), 2\% Peni-streptomycin (Gibco, Life Technologies) and 1\% fungisone (Gibo, Life Technologies). Only units with volume exceeding $70 \mathrm{ml}$ were included in the study.

\section{Separation of MNC}

UCB was delayed on Ficoll-Paque $(1,077 \mathrm{~g} / \mathrm{ml}$, Biotech Gmbh) and the buffy coat was harvested and cells washed twice in RPMI supplemented with 5\% BFS. Collected MNC were counted and tested for viability using the Trypan blue (Gibco, Invitrogen) dye exclusion method. Samples containing less than $95 \%$ viable cells were excluded.

\section{Statistics}

Associations between parameters were analysed by Mann-Whitney $\mathrm{U}$ and Anova test. Multivariate linear regression analysis was also realized to test the correlation between $\mathrm{MNC}$ and the quantitative variables. A value of $\mathrm{P}<0.05$ was considered to be significant.

\section{Results}

\section{Maternal and Neonatal Characteristics in UCB Donation}

More than 250 UCB units have been collected, but only 158 UCB units were included in the study as summarized in Table 1 . The mean maternal age was 30 years old with a range of 18-47 years. Forty three percent of them were less than 30 years old (group < 30 ) with a mean of 24.1 ; while $57 \%$ exceeded 30 years old (group $\geq 30$ ) with a mean of 36.2 years old. Maternal weight ranged from $58-102 \mathrm{Kg}$ (mean $77.09 \mathrm{~kg}$ ) while neonatal weight counted for $2.7-4.1 \mathrm{~kg}$ meaning $3.25 \mathrm{~kg}$. The donors present 1 or 2 gravid in $61.2 \%$ of the cases and $\geq 3$ gravid in $38.8 \%$. The babies are $59 \%$ female and $41 \%$ male and are mostly born after normal delivery $(51.61 \%)$. The mean MNC count was $310.9 \times 10^{6}$ with values ranging from $8 \times 10^{6}$ to $3200 \times 10^{6}\left(3.2 \times 10^{9}\right)$ cells.

\section{The Effects of Neonatal and Maternal Weight on MNC Count}

MNC count increased regarding maternal and neonatal weight in the donors group $<30$ years (Table 2). Inversely, babies with less than $3.2 \mathrm{~kg}$ were associated with higher MNC counts in the donors group $\geq 30$ years. Nevertheless, significant associations between maternal or neonatal weight with MNC count were not observed for both women groups.

\section{Relationships Between Maternal Age and Gravid Status on the MNC Count}

Table 3 showed higher MNC count in donors group $<30$ years

Table 1. Maternal and Neonatal Characteristics Relative to Collected MNC.

\begin{tabular}{|c|c|c|c|c|c|c|}
\hline & $\begin{array}{c}\text { Num- } \\
\text { ber }\end{array}$ & Mean or $(\%)$ & S.D. & Minimum & Maximum & Median \\
\hline Consent donor & 158 & & & & & \\
\hline Maternal age (years) & 158 & 30 & 7.3 & 18 & 47 & 31 \\
\hline$<30$ & 68 & $24.1(43)$ & 3.2 & 18 & 29 & 24 \\
\hline$\geq 30$ & 90 & $36.2(57)$ & 4.6 & 30 & 47 & 36 \\
\hline Gravid status & 98 & & & & & \\
\hline [1-2] & 60 & 61.2 & & & & \\
\hline$\geq 3$ & 38 & 38.8 & & & & \\
\hline Delivery type & 93 & & & & & \\
\hline Normal & 48 & 51.61 & & & & \\
\hline Caesarean & 45 & 48.39 & & & & \\
\hline Maternal weight & 98 & 77.09 & 10.9 & 58 & 102 & 74.5 \\
\hline Neonatal weight & 98 & 3.25 & 0.3 & 2.7 & 4.1 & 3.2 \\
\hline $\begin{array}{c}\text { Total MNC } \\
\text { Recovery x10 }\end{array}$ & 98 & 310.9 & 457.1 & 8 & 3200 & 186.5 \\
\hline
\end{tabular}


Table 2. The effects of Neonatal and Maternal Weight on Total MNC Count.

\begin{tabular}{|c|c|c|c|c|}
\hline Maternal age & $\begin{array}{c}\text { Neonatal and Maternal } \\
\text { weights }\end{array}$ & $\begin{array}{c}\text { Num- } \\
\text { ber }\end{array}$ & $\begin{array}{l}\text { UCB MNC x10 } \\
\text { (Median [IQR]) }\end{array}$ & $\begin{array}{c}\text { Mann-Whitney test } \\
\text { P-value }\end{array}$ \\
\hline \multirow[t]{6}{*}{$<30$ years } & Neonatal weight & 40 & & \\
\hline & $<3.2$ & 23 & 154 [84-273] & \\
\hline & $\geq 3.2$ & 17 & 246 [87-621] & $0.1629(<3.2$ vs $\geq 3.2)$ \\
\hline & Maternal weight & 40 & & \\
\hline & $<74.5$ & 29 & 158 [87-273] & \\
\hline & $\geq 74.5$ & 11 & 310 [62-621] & $0.4134(<74.5$ vs $\geq 74.5)$ \\
\hline \multirow[t]{6}{*}{$\geq 30$ years } & Neonatal weight & 58 & & \\
\hline & $<3.2$ & 26 & 223 [94-438] & \\
\hline & $\geq 3.2$ & 32 & 170 [101.5-405] & $0.9938(<3.2$ vs $\geq 3.2)$ \\
\hline & Maternal weight & 58 & & \\
\hline & $<74.5$ & 20 & 126 [88-398] & \\
\hline & $\geq 74.5$ & 38 & 209 [100-410] & $0.3596(<74.5$ vs $\geq 74.5)$ \\
\hline
\end{tabular}

IQR: Interquartile Range.

Table 3. Mutual Effects of Maternal Age Interval and Gravid Status on MNC Count.

\begin{tabular}{|c|c|c|c|c|c|c|}
\hline $\begin{array}{l}\text { Number } \\
\text { of gravid }\end{array}$ & $\begin{array}{l}\text { Maternal } \\
\text { age }\end{array}$ & Number & $\begin{array}{c}\text { UCB MNC x10 } \\
[\mathrm{IQR}])\end{array}$ & $\begin{array}{c}\text { P-value* } \\
\left(<\begin{array}{c}30 \text { years vs } \geq \\
30 \text { years })\end{array}\right.\end{array}$ & $\begin{array}{c}\text { P value } * \\
\text { n gravid vs } \\
1 \text { gravid }\end{array}$ & $\begin{array}{c}\mathbf{P} \text { value } * \\
\text { n gravid vs } 2 \\
\text { gravid }\end{array}$ \\
\hline \multirow{2}{*}{1} & $<30$ years & 14 & 224 [87-366] & 0.4713 & & 0.5247 \\
\hline & $\geq 30$ years & 15 & $186[120-280]$ & & & \\
\hline \multirow{2}{*}{2} & $<30$ years & 11 & 140 [62-284] & 0.9835 & 0.5247 & \\
\hline & $\geq 30$ years & 20 & 129 [80-470] & & & \\
\hline \multirow{2}{*}{3} & $<30$ years & 10 & 156 [96-621] & 0.5581 & 0.5085 & 0.2122 \\
\hline & $\geq 30$ years & 14 & 234.5 [104-438] & & & \\
\hline \multirow[t]{2}{*}{4} & $<30$ years & 5 & 120 [62-310] & 0.4636 & 0.7032 & 0.5036 \\
\hline & $\geq 30$ years & 8 & 315 [113-66] & & & \\
\hline
\end{tabular}

*Anova P-value

IQR: Interquartile range.

presenting 1 or 2 gravid when compared to the older ones. Indeed, theses later having 3 or 4 gravid produced more MNC in their UCB. However, none of the maternal age, nor the gravid status affected significantly the MNC count $(\mathrm{P}>0.05)$. Also, MNC count was not related to the number of gravid in both maternal groups (gravid1 vs 2, 3, $4 \mathrm{P}>0.05$; gravid 2 vs 3, $4 \mathrm{P}>0.05$ ).

\section{Multivariate Analysis of Maternal and Neonatal Factors and MNC Count}

The multivariate linear regression analysis showed that maternal age and weight, and gravid status were not influencing MNC in both maternal group (Table 4). However, newborn weight appeared to be the factor affecting significantly MNC count in the total women population $(\mathrm{P}=0.035)$.

\section{Discussion}

Advances in UCB therapeutics resulted in identifying protocols for the screening of collection units and their storage. In this con- text, two axis might be proposed, the feasibility of the process by testing the donors pre-selection, and the evaluation of safety and efficiency of collected units. Thus, most of UCB bank or processing laboratories use, in their registry inventory a multi-parameters combination such as volume and TNC as the main selection factors for suitable units. In this study, pre-selection process have been assessed.

In our series, donors aged $\geq 30$ years old had likely more chance to have a girl than a boy and this trend appeared to be common in all age intervals in Morocco, but baby's gender could not be considered as parameter influencing MNC count (unpublished data). However, higher yield of TNC or CD34+ cells with female newborn than male counterparts have been reported $[14,15]$. Elsewhere, delivery mode via caesarean sections allowed significant increase in collected units volumes as compared to vaginal deliveries [16] which was not supported by others [7, 15]. Our analysis did not focus on the collection volume of units and suggested that successful banked units might be collected either in utero or in ex utero as reported $[17,18]$. 
Table 4. Multivariate Linear Regression Analysis of Factors Associated with MNC.

\begin{tabular}{|c|c|c|c|}
\hline Group & Parameter & Coeficient & P-value \\
\hline \multirow{4}{*}{$\begin{array}{c}\text { Total } \\
\text { Population }\end{array}$} & Maternal Age & -3.54 & 0.611 \\
\cline { 2 - 4 } & Maternal Weight & -1.29 & 0.814 \\
\cline { 2 - 4 } & Gravid Status & 77.01 & 0.101 \\
\cline { 2 - 4 } & New Born Weight & 317.58 & 0.035 \\
\hline \multirow{4}{*}{ Maternal Age $<30$} & Maternal Age & -5.18 & 0.730 \\
\cline { 2 - 4 } & Maternal Weight & -1.20 & 0.879 \\
\cline { 2 - 4 } & Gravid Status & 49.26 & 0.421 \\
\cline { 2 - 4 } & New Born Weight & 356.14 & 0.084 \\
\hline \multirow{3}{*}{ Maternal Age $\geq 30$} & Maternal Age & -14.89 & 0.310 \\
\cline { 2 - 4 } & Maternal Weight & -0.11 & 0.989 \\
\cline { 2 - 4 } & Gravid Status & 90.30 & 0.204 \\
\cline { 2 - 4 } & New Born Weight & 261.85 & 0.217 \\
\hline
\end{tabular}

Previous reports have indicated that in primigravid aged $\geq 25$ years old, low density (LD) cell counts (seemed as MNC), appeared to be significantly higher than those of $\leq 24$ years old [9], suggesting that primigravid fact is in favour to higher LD cell especially in women aged $\geq 25$ years old [19]. We reported that MNC count was relevant in donors group $<30$ years with 1 or 2 gravid and that maternal age and weight might not be useful as parameters highlighting UCB quality. Also, our primigravid women did not consent to UCB donation in spite of the given cord blood information and have afraid for their first babies.

The relationships between maternal weight/obesity and UCB banking were not reported anywhere, but we showed that this parameter might be correlated indirectly to higher MNC count. At this fact, bigger babies from normal exceeding-weight donors were associated with higher yields of MNC according to other reports [20], and this association was relevant when the total donor population was considered.

This potential UCB donation profile might be considered in Morocco because it did not depend on maternal age. Especially in rural locations, many people do not have yet an official birth state thus introducing a doubt on their age. In addition, neonatal weight might be a parameter defining the first donor's profile identification helpful for UCB higher quality. The low cost characterization reported in this study is an important tool in the banking start up for a successful pre-selection of UCB units with high MNC counts. Additional testing of heamatopoietic potential will be assessed by conventionally used outcomes such as CFU and CD34+ cell counts.

\section{Conclusion}

UCB banks are created worldwide according to specific standards protocols regarding stem cell manipulation and cryopreservation while donor choice remained less standardized. The growing interest in therapeutic applications of UCB have emphasize the importance of donors search in establishing UCB banking process. To do this in Morocco, many efforts have to be displayed to involve medical authorities, professional associations, and governmental and non-governmental organizations for supporting stem cell research and banking [21].

\section{Acknowledgments}

We wish to knowledge Pr. Benhessou Mustapha for his help in collecting UCB, Balhi Iman, Belkouch Rajae, Rebroub Dounia and Dr. Hilali Malika for their contribution in the questionnaire investigation.

\section{References}

[1]. Gluckman E, Broxmeyer HA, Auerbach AD, Friedman HS, Douglas GW, et al., (1989) Hematopoietic reconstitution in a patient with a Fanconi's anemia by means of umbilical-cord blood from an HLA-identical sibling. N Engl J Med. 321(17) : 1174-1178.

[2]. Gluckman E, Rocha V (2004) Cord blood transplant: strategy of alternative donor search. Springer Semin Immunopathol. 26(1-2): 143-54.

[3]. McCullogh J, Herr G, Lennon S, Stroncek, Clay M (1998) Factors influencing the availability of umbilical cord blood for banking and transplantation. Transfusion. 38(5): 508-510.

[4]. Wagner JE, Barker JN, DeFor TE, Blazar BR, Eide C, et al., (2002) Transplantation of unrelated donor umbilical cord blood in 102 patients with malignant and non-malignant diseases : influence of CD34 cell dose and HLA disparity on treatment-related mortality and survival. Blood. 100(5): 1611-1618.

[5]. Shlebak AA, Roberts IA, Stevens TA, Syzdlo RM, Goldman JM, et al., (1998) The impact of antenatal and perinatal variables on cord blood haemopoietic stem/progenitor cell yield available for transplantation. Br J Heamatol. 103(4): 1167-71

[6]. Meyer-Monard S, Tichelli A, Troeger C, Arber C, de Faveri GN, et al. (2012) Initial cord blood unit volume affects mononuclear cell and CD34+ cell-processing efficiency in a non-linear fashion. Cytotherapy. 14 (2): 215 22.

[7]. George TJ, Sugrue MW, George SN, Wingard R (2006) Factors associated with parameters of engraftment potential of umbilical cord blood. Transfusion. 46(10): 1803-1812.

[8]. Wen SH, Zhao WI, Lin PY, Yang KL (2012) Associations among birth weight, placental weight, gestational period and product quality indicators of umbilical cord blood units. Transfus Apher Sci. 46(1): 39-45.

[9]. Omori A, Takahashi J, Hazawa M, Misaki N, Ohba H, et al., (2008) Maternal and neonatal factors associated with the high yield of mononuclear low-density/CD34+ cells from placental/umbilical cord blood. Tohoku J Exp Med. 215(1): 23-32.

[10]. Mancinelli F, Tamburini A, Spagnoli A, Malerba C, Suppo G, et al., (2006) Optimizing umbilical cord blood collection: impact of obstetric factors versus quality of cord blood units. Transplant Proc. 38(4): 1174-1176.

[11]. Urciuoli P, Passer S, CeccarelliF, Luchetti B, Paolicchi A, et al., (2010) Prebirth selection of umbilical cord blood donors. Blood Transfus. 8(1): 36-43.

[12]. Cresswell JA, Assarag B, Meski FZ, Filippi V, Ronsmans C (2015) Trends 
in health facility deliveries and caesarean sections by wealth quintile in Morocco between 1987 and 2012. Trop Med Int Health. 20(5): 607-616.

[13]. Toselli S, Gualdi-Russo E, Boulos DN, Anwar WA, Lakhoua C, et al., (2014) Prevalence of overweight and obesity in adults from North Africa. Eur J Public Health. 24(1): 31-9.

[14]. Yang H, Loutfy MR, Mayerhofer S, Shuen P (2011) Factors affecting banking quality of umbilical cord blood for transplantation. Transfusion. 51(2): 284-292.

[15]. Atanassova V, Atanassova M, Nikolov A, Zlatkov V, Mihaylova A, et al., (2012) Influence of obstetric factors on the quality of cord blood units collected for allogeneic transplantation. Akush Ginekol (Sofia). 51b(2): 11-6.

[16]. Takashi Yamada, Yukiko Okamoto, Hajime Kasamatsu, Yoshinori Horie, Naoko Yamashita, et al., (2000) Factors affecting the volume of umbilical cord blood collections. Acta Obstet Gynecol Scand. 79(10): 830-833.

[17]. Lasky Larry C, Lane Thomas A, Miller John P, Lindgren Bruce, Patterson
Heidi A, et al., (2002) In utero or ex utero cord blood collection: which is better? Transfusion. 42(10): 1261-1267.

[18]. Tamburini A, Malerba C, Mancinella F, Spagnoli A, Ballatore G, et al., (2006) Evaluation of biological features of cord blood units collected with different methods after caesarean section. Transplant Proc. 38(4): 11711173.

[19]. Al-Sweedan SA, Musalam L, Obeidat B (2013) Factors predicting the hematopoietic stem cells content of the umbilical cord blood. Transfus Apher Sci. 48(2): 247-52.

[20]. Ballen KK, Wilson M, Wu J, Ceredona AM, Hsieh C, et al., (2001) Bigger is better: maternal and neonatal predictors of hematopoietic potential of umbilical cord units. Bone Marrow Transplant. 27(1): 7-14.

[21]. Mazini L, Matar N, Bouhya S, Marzouk D, Anwar W, et al., (2014) Umbilical Cord Blood Banking for Transplantation in Morocco: Problems and opportunities. J Stem Cells Regen Med. 10(2): 28-37. 